\title{
IN VITRO COMPARATIVE STUDY OF MODULUS OF ELASTICITY BETWEEN DENTINE SUBSTITUTE AND FLOWABLE COMPOSITE RESIN
}

\author{
Doaa Helmy*, Ibrahim Lotfy El Gayar*, Mona Ghoniem*** and Maha Adly****
}

\begin{abstract}
Objectives: This study will analyze the modulus of elasticity of novel smart dentine replacement (SDR) and a flowable composite resin when used as a base material under composite restoration.

Materials: 1. Smart Dentine Replacement (SDR)

$$
\text { 2. X-flow (flowable composite) }
$$

Methods: Forty eight specimens will be fabricated for elastic modulus test. The specimens will be divided into two groups, twenty four specimens of SDR and twenty four specimens of X-flow. Each group will be further divided according to the aging condition into three subgroups, each subgroup contain eight specimens. In which modulus of elasticity will be measured after $24 \mathrm{hrs}$ and then measured after storage in distilled water for one month then measured after storage in distilled water for three months. Then the data will be statistically analysed.
\end{abstract}

Results: Elastic modulus of both Surefil SDR and X-Flow increases with the increase in the storage period in distilled water.

Conclusion: SDR has higher elastic modulus than X-Flow.

\section{INTRODUCTION}

Flowable composite chemistry is based on traditional hybrid composites, but generally the composites contain smaller filler concentrations. ${ }^{(1)}$ As a result, these materials are less rigid and have modulus of elasticity lower than conventional hybrid composite. ${ }^{(2)}$ Flowable composite have higher flow, better adaptation to the internal cavity wall, easier insersion and greater elasticity than previously available products. ${ }^{(3)}$

Composites present an inherent disadvantage consisting of polymerization shrinkage during setting.(4) Polymerization shrinkage can result in gap formation between cavity walls and composite resin. ${ }^{(5)}$ Gap formation contributes to microleakage, permitting the passage of bacteria and oral fluids

\footnotetext{
* Demonestrator of Operative Dentistry, Faculty of Dentistry, Pharos University

** Professor of Operative Dentistry, Faculty of Dentistry, Alexandria University

*** Assistant Professor of Operative Dentistry, Faculty of Dentistry, Alexandria University

**** Assistant Professor of Dental Biomaterials, Faculty of Dentistry, Alexandria University
} 
from the oral cavity. ${ }^{(6)}$ Post-operative sensitivity, pulpal inflammation and secondary caries may occur because of microleakage. ${ }^{(7)}$

Flowable composite have been proposed as liners, fissure sealants and restorative material for small cavities. ${ }^{(8)}$ Their high ability to flow during the polymerization reaction might provide more contraction stress relaxation reducing the occurrence of marginal microleakage formation and debonding, when used as liners underneath traditional composites. ${ }^{(9)}$

An elastic bonding area at the tooth resin interface has been proposed as an inherent buffer to compensate for polymerization contraction stress and occlusal stress on the restorative resin. ${ }^{(10)}$ A currently used practical technique for the creation of elastic bonding areas involves applying a layer with a relatively low modulus of elasticity as an intermediary between the composite and the tooth. ${ }^{(11)}$

Van Meerbeek and colleagues confirmed the effectiveness of flexible and low viscosity intermediate layers as shock absorbers. ${ }^{(10,12)}$ The relationship between the elastic moduli of these layers is referred to as the "Elastic cavity wall concept". ${ }^{(1)}$ So it reduces mariginal leakage as a result of the stress relief function of these materials. ${ }^{(10)}$

Elastic moduli are key parameters in describing the deformation behavior of the materials. ${ }^{(13)}$ For occlusal, stress bearing restorations, the modulus must be high to withstand occlusal forces and deformation. ${ }^{(14)}$ The properties of resin composites depend primarily on their material composition. Correlations between filler content and mechanical properties are established for modulus of elasticity, the higher the filler content, the higher the modulus and the greater the resistance to deformation. Conversely, the lower the filler content, the greater the expected polymerization shrinkage and lower the ability to resist deformation. ${ }^{(15)}$

The stress magnitude is dependent on c-factor, the ratio of bonded to free surfaces involved. ${ }^{(16)}$ The cavities which have high c-factor, where stress relief due to flow is severely limited and the contraction stress might exceed the bond strength. ${ }^{(16,17)}$ Moreover, mechanical properties of the composite most close to the interface might be compromised if the curing light loses too much intensity due to attenuation before reaching the bottom of the cavity. ${ }^{(18)}$

A tight marginal seal still is the primary goal for the clinician, because once happened gap formation cannot be counteracted with restorative materials that prevent demineralization along with cavity margins. ${ }^{(19,20)}$

Simplifications in resin composite materials have been less frequently reported during the last decade in adhesive dentistry. There was definitely improvement in the field of polymerization shrinkage and wear resistance, however, a meticulous incremental layering technique is still mandatory to meet the mentioned prerequisites for effective sealing of margins of resin composite restorations. ${ }^{(21-25)}$

Recent advances by manufactures have resulted in bulk-fill flowable resin base being marketed for use beneath conventional resin base cement materials, with a reported depth of cure in excess of $4 \mathrm{~mm}$. ${ }^{26-}$ ${ }^{28)}$ Whilst the manufacturers claims that the modified methacrylate resin has a slow polymerization rate through the use of a polymerization modulator. ${ }^{(27-}$ 30) SDR have higher filler content and are claimed to have increased mechanical properties, thus they are now for recommended for larger posterior restorations. ${ }^{(31)}$ To simplify the filling procedure and to save precious chair time. ${ }^{(29)}$

The novel SDR Resin technology is a urethane di-methacrylate structure that is responsible for the reduction in polymerization shrinkage and stress. SDR has very low overall shrinkage compared to other conventional flowable composites. Lower volumetric shrinkage contributes to overall lower shrinkage stress. This is due in part of the larger size of the SDR resin compared to conventional resin 
systems (molecular weight of $849 \mathrm{~g} / \mathrm{mol}$ for SDR resin compared to $513 \mathrm{~g} / \mathrm{mol}$ for Bis-GMA). ${ }^{(32)}$

SDR or surefil SDR was introduced to the market as flowable resin composite claiming that it would allow a $4 \mathrm{~mm}$ bulk placement in one layer and being mandatorily covered by a $2 \mathrm{~mm}$ layer of conventional resin composite. ${ }^{(22,30)}$ Although flowable resin composite materials have been repeatedly discussed to act as stress breakers or adaptation promotors, clinical investigations could not confirm this issue so far. ${ }^{(33)}$ Up till now there is only one study describing relevant parameters for SDR, however, polymerization stress was reported to be considerably lower than for conventional flowable materials. ${ }^{(30)}$

Therefore, the objective of the present study was to compare the modulus of elasticity of the novel SDR and the flowable composite resin when used as a base material under composite restoration.

\section{MATERIALS AND METHODS}

Materials used in this study

TABLE (1) Characteristics of composite resins tested

\begin{tabular}{|c|c|c|c|c|c|}
\hline $\begin{array}{l}\text { Restorative } \\
\text { Materials }\end{array}$ & $\begin{array}{c}\text { Filler } \\
\text { Volume (\%) }\end{array}$ & $\begin{array}{c}\text { Filler weight } \\
(\%)\end{array}$ & $\begin{array}{l}\text { Filler } \\
\text { type }\end{array}$ & $\begin{array}{l}\text { Organic } \\
\text { matrix }\end{array}$ & Manufacture \\
\hline $\begin{array}{c}\text { Smart } \\
\text { Dentine } \\
\text { Replacement } \\
\text { (Surefil SDR) }\end{array}$ & $44 \%$ & $68 \%$ & $\begin{array}{l}\text { 1-Barium- } \\
\text { alumino- } \\
\text { fluoro } \\
\text { borosilicate } \\
\text { glass } \\
\text { 2-Strontium } \\
\text { alumino- } \\
\text { fluoro-silicate } \\
\text { glasses }\end{array}$ & $\begin{array}{l}\text { 1-Modified UDMA } \\
\text { 2-EBP-ADMA } \\
\text { 3-Titanium dioxide } \\
\text { 4-Iron oxide pigments } \\
\text { 5-Camphorquinone } \\
\text { (CQ) photoinitiator } \\
\text { 6-Butylated hydroxyl } \\
\text { toluene } \\
\text { 7- UV Stabilizer }\end{array}$ & $\begin{array}{l}\text { DENTSPLY } \\
\text { Detrey Gmbh, } \\
\text { De-Trey-Str.1, } \\
\text { D-78467 } \\
\text { Konstanz, } \\
\text { GERMANY. }\end{array}$ \\
\hline X-Flow & $41 \%$ & $61 \%$ & $\begin{array}{l}\text { 1-Barium } \\
\text { fluoro } \\
\text { alumino- } \\
\text { boro silicate } \\
\text { glass }(1 \mu \mathrm{m}) \\
\text { 2-Nanofiller } \\
\text { silica } \\
(<0.02 \mu \mathrm{m})\end{array}$ & $\begin{array}{l}\text { 1-Urethane modified } \\
\text { BisGMA-adduct } \\
\text { 2-BisGMA } \\
\text { 3-Diluents }\end{array}$ & $\begin{array}{l}\text { DENTSPLY } \\
\text { Detrey Gmbh, } \\
\text { De-Trey-Str.1, } \\
\text { D-78467 } \\
\text { Konstanz, } \\
\text { GERMANY }\end{array}$ \\
\hline
\end{tabular}




\section{Elastic modulus test}

Compressive modulus of elasticity test was used to determine the modulus of elasticity of the specimens by drawing the compressive stress-strain curves. ${ }^{(116)} \mathrm{A}$ total of forty eight specimens were fabricated. The specimens were divided into two groups, twenty four specimens each, as follows:

- Group 1: twenty four specimens of Surefil SDR.

- Group 2: twenty four specimens of X-Flow.

Each group was further subdivided according to the aging condition into three subgroups, each subgroup contain eight specimens:

- Subgroup A: Elastic modulus was measured for eight specimens after storage in distilled water for $24 \mathrm{hrs}$.

- Subgroup B: Elastic modulus was measured for eight specimens after storage in distilled water for one month.

- Subgroup C: Elastic modulus was measured for eight specimens after storage in distilled water for three months.

Aging was carried out in distilled water at $37^{\circ} \mathrm{C}$. (31) Distilled water was changed weekly to avoid alteration of the $\mathrm{pH}$, for 3 months. ${ }^{(32)}$

\section{Each specimen was prepared as follows:}

A custom made cylindrical Teflon mold was used to fabricate the specimens. The specimens' dimensions were $2 \mathrm{~cm}$ length and $1 \mathrm{~cm}$ width (due to technical reasons). Composite was condensed incrementally into the Teflon mold and light cured for 40 seconds. $^{(33)} \mathrm{A}$ glass slide was placed on the top of the molds and gentle pressure was applied to extrude excess materials. The surface of the specimen was light cured for 40 seconds. ${ }^{(31)}$

The small excess of material was removed by using a stain steel blade applied parallel to the mold's surface. After the removal of the specimen from the mold, an additional curing was done. ${ }^{(33)}$ The specimens were divided according to the storage conditions mentioned previously in the subgroups (A to C).

Each specimen from the previously mentioned subgroups was loaded in the universal testing machine* between pistons at the same rate with a gradual load 50 kilo. ${ }^{(33)}$ The crosshead speed was set as $1 \mathrm{~mm} / \mathrm{min}$ until fracture. The modulus of elasticity of the resin composites was defined as the slope from their stress-strain curve in the elastic deformation region. ${ }^{(34)}$

\section{RESULTS}

Comparison between the 2 groups is listed in Table 2. To compare the 2 groups, Mann Whitney test was applied. As $\mathrm{P}$ values came out to be statistically significant in the 2 groups. However, no significant difference was found after storage in distilled water for 24 hours. So the comparison revealed significant differences in the mean elastic modulus of the 2 groups except for those stored in distilled water for 24 hours

TABLE (2) Comparison between the 2 groups according to elastic modulus.

\begin{tabular}{|c|c|c|c|c|}
\hline $\begin{array}{c}\text { Elastic } \\
\text { modulus }\end{array}$ & $\begin{array}{c}\text { Surefil SDR } \\
(\mathbf{n}=\mathbf{8})\end{array}$ & $\begin{array}{c}\text { X-Flow } \\
(\mathbf{n = 8})\end{array}$ & $\mathbf{Z}$ & $\mathbf{P}$ \\
\hline $\begin{array}{c}\text { After 24 Hours } \\
\text { Min. - Max. }\end{array}$ & $2.35-4.71$ & $2.35-3.14$ & & \\
Mean \pm SD & $3.04 \pm 0.78$ & $2.55 \pm 0.36$ & 1.650 & 0.099 \\
Median & 3.14 & 2.35 & & \\
\hline After 1 Month & & & & \\
Min. - Max. & $3.14-4.71$ & $2.35-4.71$ & & \\
Mean \pm SD & $4.51 \pm 0.56$ & $3.14 \pm 0.73$ & $2.893^{*}$ & $0.004^{*}$ \\
Median & 4.71 & 3.14 & & \\
\hline After 3 Months & & & & \\
Min.- Max. & $6.79-8.89$ & $4.71-6.10$ & & \\
Mean \pm SD & $7.84 \pm 0.97$ & $5.28 \pm 0.52$ & $3.338^{*}$ & $0.001^{*}$ \\
Median & 7.87 & 5.45 & & \\
\hline
\end{tabular}

Z: Z for Mann Whitney test for comparing between Surefil SDR and X-Flow

*: Statistically significant at $p \leq 0.05$ 
The Surefil SDR stored in distilled water for 3 months showed the highest mean elastic modulus $(7.84 \pm 0.97 \mathrm{GPa})$ while X-Flow stored in distilled water for 24 hours showed the lowest mean elastic modulus $(2.55 \pm 0.36 \mathrm{GPa})$. The data is presented using bar chart (fig. 1).

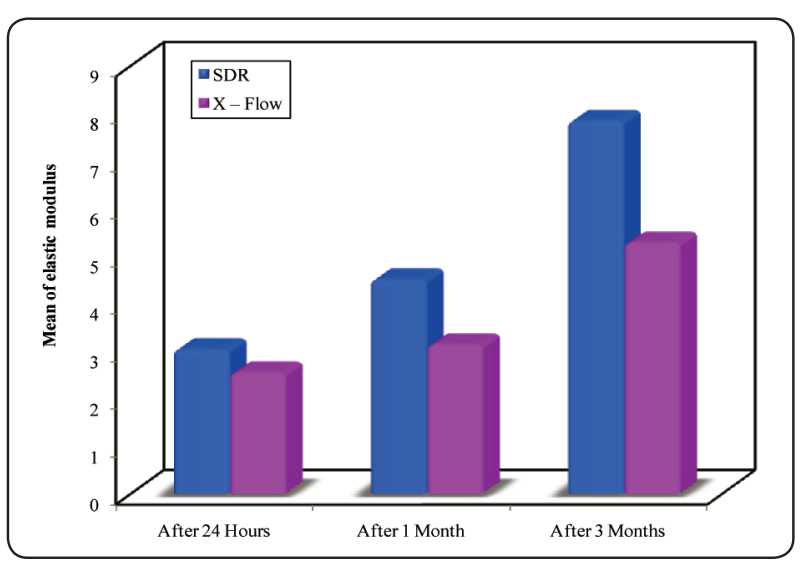

Fig. (1) Bar chart showing the comparison between the 2 groups according to elastic modulus.

\section{DISCUSSION}

Time-saving restorative materials are an ongoing demand for posterior applications. Thus, a new resin based composite material class, the bulk-fill resin composite, has been introduced in the past few years. They are an attempt to speed up the restoration process by enabling up to $4 \mathrm{~mm}$ thick increment to be cured in one step, thus skipping the time consuming layering process. Bulk-fill resin composites are also marketed as restoratives that are particularly well suited for patients with limited compliance. Moreover, the rheology of these materials is thought to be changed, thus allowing a better adaption to the cavity walls and resulting in a self-leveling effect. ${ }^{(35)}$ These materials are indicated for use as flowable base materials to be veneered with $2 \mathrm{~mm}$ of posterior composite. ${ }^{(36)}$ So in this study Surefil SDR was used as a bulk fill resin composite.

Restorative materials are exposed to the oral environment throughout their lifetime, and it is vital to understand the properties of these composite resins in hydrated conditions. Findings of many studies have shown significant changes in the mechanical properties of resin composite resins due to aging in water ${ }^{(37)}$ as using of distilled water avoid the complications that arises when using different formulations of different saliva. ${ }^{(38)}$

The elastic modulus of dental composites is one of the key mechanical properties which may influence the length of service of these materials. The elastic modulus relates to stiffness of a material and is defined mathematically as the slope of the stress-strain curve within the proportional limit. The modulus of elasticity is directly related to the amount of deformation when the material subjected to external forces. Hence, the dental composites used in posterior restorations must possess an adequate modulus value in order to withstand the high masticatory forces. The elastic modulus of the dental restorative materials should be close to that of enamel and dentine to allow better stress distribution. The existence of large modulus gradient between restorative materials and dental hard tissues may lead to fracture and marginal failure. ${ }^{(39)}$

Elastic modulus test depends on producing excellent quality specimens and the quality of the surfaces and edges of the specimens is particularly critical in order to prevent premature fractures from occurring. Flat and parallel surfaces will be achieved by forming them between glass slides. An important feature of this test is the use of a standardized and controlled torque in order to prevent bending of the specimen during testing. ${ }^{(40)}$ This was done in the current study.

In this study, Surefil SDR showed higher elastic modulus values when compared to X-Flow. The explanation for these results may be due to the filler content which is considered to be the most valuable factor concerning the improvement of the mechanical properties of resin based composites. (41) As the material with the highest filler content achieved the highest modulus of elasticity. ${ }^{(42)}$ So Surefil SDR have higher elastic modulus than 
$\mathrm{X}$-Flow, as the filler loading is higher for Surefil SDR than X-Flow.

These results are in agreement with (Xavier JC et al., 2010) ${ }^{43}$, (Srivastava VK, 2011) ${ }^{44}$, (Salerno M et al., 2011) ${ }^{45}$, (Srivastava VK and Singh S, 2012) ${ }^{46}$, (Boaro LC et al., 2013) $^{32}$, (Balos S et al., 2013) ${ }^{47}$, (Ilie N et al., 2013) ${ }^{48}$ and (Leprince JG et al., 2014) ${ }^{49}$ as they stated that the heavier filler loading results in higher elastic modulus. But in disagreement with the results of (Hirayama S et al., 2014) (50 $^{5}$ as they stated that there is no relation between filler loading and elastic modulus.

In this study, there was a significant increase in elastic modulus values for both materials Surefil SDR and X-Flow after water aging for 24 hours, one month and three months. The explanation for these results may be due to the polymerization reaction will be continued. ${ }^{(51)}$ Another explanation may be due to slow degree of conversion or composite post-cure which refers to progressive cross--linking reactions in composite after light curing. ${ }^{(52,53)}$ Another explanation may be due to the presence of fillers in the composites which have major influences in the elastic modulus values; because even softening of composite matrix due to water penetration had no effect on the decrease on the stiffness and hardness of the composite. ${ }^{(54)}$

These results is in accordance with (Gladys S et al., 1995) ${ }^{51}$ who found that there is slight increase in the elastic modulus of the composites resin in the period of one month during storage in water, (Nainan MT and Satish G, 2006) ${ }^{53}$, (Papadogiannis DYet al., 2008) $)^{55}$ who stated that Filtek P60 exhibited an increase in the elastic modulus after one month during storage in water and (Karimzadeh A et al., $2014)^{56}$ But, in disagreement with the results of (Attar $\mathrm{N}$ and Ciftci Y, 2006) $^{57}$

and (Ateyah N, 2013) ) $^{58}$ as they stated that elastic modulus of composites resin remains stable while storage in water. Others studies by (Abe $\mathrm{Y}$ et al., 2001) $)^{59}$, (Fong H, 2004) ${ }^{60}$ and (Alomayri T et al., $2014)^{61}$ revealed a decrease in elastic modulus values after water aging. The reason for these results may be due water has a plasticizing effect on the matrix and that it may degrade the filler-matrix interface. ${ }^{(62)}$ Debonded fillers may then act as stress concentrators, which significantly multiply the number of potential crack growth sites. Therefore, water absorption results in a slight decrease in resistance to deformation. ${ }^{(63)}$

\section{REFERENCES}

1. Bayne SC, Thompson JY, Swift EJ, Stamatiades P, Wilkerson M. A characterization of first generation flowable composites. J Am Dent Assoc 1998;129:567-77.

2. Labella R, Lambrechts P, Nan Meerbeek B, Vanherle G. Polymerization shrinkage and elasticity of flowable composites and filled adhesives. Dent Mater 1999;15:128-37.

3. Payne JH 4th. The marginal seal of class 2 restoration: flowable composite resin compared to injectable glass ionomer. J clin prediatr Dent 1999;23:123-130.

4. Attar N, Turgut MD, Gungor CH. The effect of flowable composite resins as gingival increments on the microleakage of posterior resin composite. Oper Dent 2004;29:162-167.

5. Davidson CL, de Gee AJ, Feilzer A. The competition between the composite dentine bond strength and the polymerization contraction stress. J Dent Res 1984;63:1396-1399.

6. St georges AJ, Wilder AD Jr, Perdigao J, Swift EJ Jr. Microlekeage of class 5 composites using different placement and curing techniques: an in vitro study. Am J Dent 2002;15:244-247.

7. Bergenholtz G, Cox CF, Coesche WJ, Sayed SA. Bacterial leakage around dental restorations: its effect on the dental pulp J oral pathol 1982;11:439-450.

8. Helvatjoglu-Antoniades M, Papadogiannis Y, Lakes RS, Dionysopoulos P, Papadogiannis D. Dynamic and static elastic moduli of packable and flowable composite resins and their development after initial photo curing. Dental Mater 2006;22:450-9.

9. Leevailoj C, Cochran MA, Matis BA, Moore BK, Platt JA. Microlekeage of posterior packable resin composites with and without flowable liners. Oper Dent 2001;26:302-7.

10. Edelhoff D, Spiekermann H, Yildirim M. Metal-free inlayretained fixed partial dentures. Quintessence Int 2001; 32:269-281. 
11. Eskitaflcioglu G, Belli S, Kalkan M. Evaluation of two post core systems using two different methods (Fracture strength test and a finite elemental stress analysis study). J Endodont 2002;28:629-633.

12. Fennis WMM, Tezvergil A, Kuijs RH, Lassila LVJ, Kreulen CM. Creugers NHJ, Vallittu PK, In vitro fracture resistance of fiber reinforced cusp-replacing composite restorations. Dent Mater 2005;21:56.

13. Chung SM, Yap AU, Koh WK, Tsai KT, Lim CT. Measurement of Poisson's ratio of dental composite restorative materials. Biomaterials 2004;25:2455-60.

14. Unterbrink GL, Liebenberg WH. Flowable resin composites as filled adhesives: literature review and clinical recommendations. Quintessence Int 1999;30:24957.

15. Braem M, Finger W, Doren VEV, Lambrechts P, Vanherle G. Mechanical properties and filler fraction of dental composites. Dental Materials 1989;5:346-8.

16. Feilzer AJ, de Gee AJ, Davidson CL. Setting stress in composite resin relation to configuration of the restoratives. Journal of Dental Research 1987;66:1636-9.

17. Yoshikawa T, Sano H, Burrow MF, Tagami J, Pashley DH. Effects of dentine depth and cavity configuration on bond strength. Journal of Dental Research 1999;78:898-905.

18. Peutzfeldt A, Asmussen E. Resin composite properties and energy density of light cure. Journal of Dental Research 2005;84:659-62.

19. Kramer N, Garcia-Godoy F, Frankenberger R. Evaluation of resin composite materials. Part 2. In vivo investigations. American Journal of Dentistry 2005;18:75-81.

20. Van Dijken JW. Durability of resin composite restorations in high c-factor cavities: a 12 year follows up. Journal of Dentistry 2010;38:469-74.

21. Ernst CP, Canbek K, Aksogan K, Willershausen B. Two-year clinical performance of a packable posterior composite with and without a flowable composite liner. Clinical oral Investigations 2003;7:129-34.

22. Burgess J, Cakir D. Comparative properties of lowshrinkage composite resins. Compendium for continuing Education in Dentistry 2010;31:10-5.

23. Kramer N, Garcia-Godoy F, Reinelt C, Feilzer AJ, Frankenberger R. Nanohybrid vs. fine hybrid composite in extended class 2 cavities after six years. Dental Materials 2011;27:455-64.

24. Frankenberger R, Lohbauer U, Roggendorf MJ, Naumann M, Taschner M. Selective enamel etching reconsidered: better than etch-and-rinse and self-etch? Journal of Adhesive Dentistry 2008;10:339-44.

25. Van Dijken JW, Pallesen U. Clinical performanceof a hybrid resin composite with and without an intermediate layer of flowable resin composite: a 7-year evaluation. Dental Materials 2011;27:150-6.

26. Product specification for SDR (Dentsply Caulk, Milford, DE, USA).

27. Product specification for $\mathrm{x}$-tra base (Voco $\mathrm{GmbH}$, Cuxhaven, Germany).

28. Campodonico CE, Tantbirojn D, Olin PS, Versluis A. Cuspal deflection and depth of cure in resin-based composite restorations filled by using bulk, incremental and transtooth illumination techniques. Journal of the American Dental Association 2011;142:1176-82.

29. Roggendorf MJ, Kramer N, Appelt A , Naumann M, Frankenberger R. Marginal quality of flowable $4 \mathrm{~mm}$ base vs. Conventionally layered resin composite. Journal of Dentistry 2011;39:643-7.

30. Ilie N, Hickel R. Investigation on a methacrylate-based flowable composite based on SDRTM technology. Dental Materials 2011;27:348-55.

31. Chung SM, Yap AU, Tsai KT and Yap FL. Elastic modulus of resin based dental restorative materials: A microindentation approach. J Biomed Mater Res B Appl Biomater 2005; 72: 246-53.

32. Boaro LC, Goncalves F, Guimaraes TC, Ferracane JL, Pfeifer CS and Braga RR. Sorption, solubility, shrinkage and mechanical properties of "low shrinkage" commercial resin composites. Dent Mater. 2013;29:398-404.

33. Masouras K, Silikas N and Watts DC. Correlation of filler content and elastic properties of resin composites. Dent Mater. 2008;24:932-39.

34. Benetti AR, Peutzfeldt A, Lussi A and Flury S. Resin composites: Modulus of elasticity and marginal quality. J of Dent. 2014;42:1185-1192.

35. Ilie N, Bucuta S and Draenert M. Bulk-fill Resin-based Composites: An In Vitro Assessment of Their Mechanical Performance. Operative Dentistry. 2013;38:618-25.

36. El-Safty S, Silikas N and Watts DC. Creep deformation of restorative resin composites intended for bulk-fill placement. Dental Materials. 2012;28(8):928-935.

37. Shah MB, Ferracane JL and Kruzic JJ. Mechanistic aspects of fatigue crack growth behavior in resin based dental restorative composites. Dent Mater.2009;25(7):909-16. 
38. Leung VW and Darvell BW. Artificial salivas for in vitro studies of dental materials. J Dent. 1997;25(6):475-84.

39. Lambrechts P, Braem M, Vanherle G. Evaluation of clinical performance for posterior composite resins and dentine adhesives. Oper Dent 1987;12:53-78.

40. Nomoto R, Carrick TE and McCabe JF. Suitability of a shear punch test for restorative materials. Dent Mater. 2001;17:415-21.

41. Braem M, Lambrechts P, Van doren V, Vanherle G. The impact of composite structure on its elastic response. J Dent Res 1986;65:648-53.

42. Ilie N, Bucuta S and Draenert M. Bulk-fill Resin-based Composites: An In Vitro Assessment of Their Mechanical Performance. Operative Dentistry. 2013;38:618-25.

43. Xavier JC, Monteiro GQ and Montes MA. Polymerization shrinkage and flexural modulus of flowable dental composite. Mater Res 2010; 13: 381-4.

44. Srivastava VK. Enhancement of elastic modulus of epoxy resin with carbon nanotubes. WJNSE 2011; 1: 1-6.

45. Salerno M, Derchi G, Thorat S, Ceseracciu L, Ruffilli $\mathrm{R}$ and Barone AC. Surface morphology and mechanical properties of new generation flowable resin composites for dental restoration. Dent Mater 2011; 27: 1221-8.

46. Srivastava VK and Singh S. A micro-mechanical model for elastic modulus of multi-walled carbon nanotube/epoxy resin composites. International Journal of Composite Materials 2012; 2: 1-6.

47. Balos S, Pilic B, Petronijevic B, Markovic D, Mirkovic S and Sarcev I. Improving mechanical properties of flowable dental composite resin by adding silica nanoparticles. Vojnosanit Pregl 2013; 70: 477-83.

48. Ilie N, Bucuta S and Draenert M. Bulk-fill Resin-based Composites: An In Vitro Assessment of Their Mechanical Performance. Operative Dentistry. 2013;38:618-25.

49. Leprince JG, Palin WM, Vanacker J, Sabbagh J, Devaux J, Leloup G. Physico-mechanical characteristics of commercially available bulk fill composites. J Dent 2014; 42: 993-1000.

50. Hirayama S, Iwai H and Tanimoto Y. Mechanical evaluation of five flowable resin composites by the dynamic microindentation method. J Dent Biomech 2014.

51. Gladys S, Van Meerbeek B, Braem M, Lambrechts P, Vanherle G. Comparative physico-mechanical characterization of new hybrid restorative materials with conventional glass-ionomer and resin composite restorative materials. J Dent Res 1997;76:883-94.

52. Munksgaard EC. Changes in expansion and mechanical strength during water storage of a traditional and three modified resin composites. Acta Odontol Scand 2002; 60 203-207.

53. Nainan MT and G Satish. Invitro evaluation of flexural strength and flexural modulus of elasticity of different composite restoratives. Journal of Conservative Dentistry. 2006;9:140-147.

54. Curtis A, Shortall A, Marquis P and Palin W. Water uptake and strength characteristics of a nanofilled resin-based composite. Journal of Dentistry. 2008;36:186-193.

55. Papadogiannis DY, Lakes RS, Papadogiannis Y, Palaghias $G$ and Helvatjoglu-Antoniades $M$. The effect of temperature on the viscoelastic properties of nano-hybrid composites Dent Mater. 2008;24:257-266.

56. Karimzadeh A, Ayatollahi MR and Shirazi HA. Mechanical Properties of a Dental Nano-Composite in Moist Media Determined by Nano-Scale Measurement. IJMMM 2014; 2: 67-72.

57. Attar $\mathrm{N}$ and Ciftci Y. A comparison of the flexural strength and elastic modulus of condensable and hybrid composite resins. Journal of Hacettepe Faculty of Dentistry 2006; 30 : 42-50.

58. Ateyah N. Mechanical behavior of water aged nano-filled hybrid composite retoratives. Journal of Dental Science. 2013;4(1):21-25.

59. Abe $Y$, Lambrechts $P$, Inoue S, Braem MJ, Takeuchi M, Vanherle G, et al. Dynamic elastic modulus of packable composites. Dent Mater 2001; 17: 520-5.

60. Fong $H$. Effects of water contents and postcuring conditions on Bis-GMA/TEGDMA dental restorative composite resins. J Appl Polym Sci 2004; 94: 492-502.

61. Alomayri T, Assaedi H, Shaikh FUA and Low IM. Effect of water absorption on the mechanical properties of cotton fabric-reinforced geopolymer composites. Journal of Asian Ceramic Societies. 2014;2(3):223-230.

62. Soderholm KJM and Roberts MJ. Influence of water exposure on the tensile strength of composites. Journal of Dental Research. 1990;69:1812-6.

63. Braem MJA, Davidson CL, Lambrechts P and Vanherle G. In vitro flexural fatigue limits of dental composites. Journal of Biomedical Materials Research. 1994; 28:1397-402. 